\title{
Exploration and Experimentation on the Weight and Density of Substances in the Sixteenth and Early Seventeenth Centuries: Introduction
}

\author{
Cesare Pastorino \\ Technische Universität Berlin, Berlin, Germany \\ cesare.pastorino@gmail.com
}

The second half of the sixteenth century saw a renewed interest among European scholars in the quantitative investigations of the weight and density of substances. Attempts to estimate the specific weights of particular substances were not new. Early numerical determinations for common metals, or materials like oil, wine and honey, were already available in the Renaissance from a variety of sources, including classical texts and medieval technical manuscripts. ${ }^{1}$ Also, medieval Arabic scholars had developed extremely sophisticated examinations of the specific gravities of many substances, which however were entirely unknown to the Renaissance authors of the Latin west. ${ }^{2}$ It is fair to say then that the time between the mid-sixteenth century and the first few decades of the seventeenth century marked the origins of an extensive experimental program - still not fully investigated in the literature as a whole - for the study in Europe of the weights of substances. Apart from Thomas Harriot, Francis Bacon and Johannes Kepler - the scholars considered in three of the essays in this special issue - it is worth recalling other figures who also embarked on significant explorations during this time. Among others, the cases of Niccolò Tartaglia, François de Foix de Candale, Jean Bodin, Juan Bautista Villalpando, Galileo Galilei and Marino Ghetaldi stand out. All of these authors

1 For instance, the pseudo-Galenic treatise De ponderibis et mensuris provided the proportions 72:80:108 for the weights of oil, wine and honey, respectively. Johan van Heurne, in the Praxis medicinae nova ratio (Leiden, 1590), attributed to Galen a different choice of proportion, that is to say 9:10:15. Also, estimates of the specific gravities of common metals were present in the medieval Carmen de ponderibus and Mappae clavicula; see Marshall Clagett, The Science of Mechanics in the Middle Ages (Madison, WI, 1959), 85-96.

2 Especially Al-Bīrūnī (973?-1048) and Al-Khāzinī (fl. 1115-1131); see Heinrich Bauerreiß, Zur Geschichte des spezifischen Gewichtes im Altertum und Mittelalter (Erlangen, 1914); Mohammed Abattouy, "Khāzinī, Abū al-Fatḥ 'Abd Raḥmān al-," in The Oxford Encyclopedia of Philosophy, Science, and Technology in Islam. Oxford Islamic Studies Online, <www.oxfordislamicstudies. com/article/opr/t445/e129>, accessed 22 June 2020. 
- in different ways and often with very different motivations - conducted extensive measurements of the specific weights of a large number of substances and objects, including coins and precious stones. ${ }^{3}$

In the title of this special issue, I refer to these investigations as "explorations." This is not a casual choice. As the following articles will show, these early observations and experiments on the weights of substances produced a considerable number of preliminary measurements and results, which were not however obtained through a univocal, consolidated method, and which, overall, did not fit into a conclusive and coherent picture. The investigations documented in this issue are not accounts of crucial discoveries, or confirmations of overarching theories, but explorations of what was perceived as a still largely unknown experimental landscape (what Friedrich Steinle has fittingly called 'exploratory experimentation'). ${ }^{4}$ As mentioned, investigations and measurements produced a substantial collection of data. In the time span under consideration, the number of things and substances which had had their weights investigated grew from the small assortment considered by classical authors - like water, wine, oil and the metals - to a remarkable number and variety. The most spectacular case of this sort of accumulation can be found in the almost Rabelaisian list of measured substances in Francis Bacon's Historia densi et rari, which included the weighing of things as diverse as mutton flesh, pearl powder, ox horns, Indian balsam, raw calves' brains, sheep's blood, red sandalwood, jet, fresh onion and cow's milk. ${ }^{5}$ Also, as Silvia Manzo's article shows, interpretations on the increase of the weight of metals in mines and during calcination developed in a haphazard way, alternating between acceptance and rejection of traditional and new explanations, among several disciplines (medicine, mineralogy, chemistry).

For the natural philosophers here considered, the investigation of the weights and densities of substances was always intended as a means to develop knowledge about the properties of matter. "A philosopher could learn a lot from the diligent observation of the weight of every substance, and oftentimes more than an alchemist from fire," stated Kepler at the beginning of his

3 See, for instance, Niccolò Tartaglia, Ragionamenti [...] sopra la sua travagliata inventione (Venice, 1551); Galileo Galilei, Tavola delle proporzioni delle gravità in specie de i metalli e delle gioie pesate in aria ed in aqqua, in Antonio Favaro, ed., Le Opere di Galileo Galilei, vol. I (Florence, 189o), 221-228. For the other authors cited here, see the specific references in the articles by Stephen Clucas and Cesare Pastorino in this issue.

4 On 'exploratory experiments,' see Friedrich Steinle, Explorative Experimente: Ampère, Faraday und die Ursprünge der Elektrodynamik (Stuttgart, 2005); Engl. trans., Exploratory Experiments. Ampère, Faraday, and the Origins of Electrodynamics (Pittsburgh, PA, 2016).

5 Francis Bacon, The Instauratio magna: Last Writings, ed. Graham Rees (Oxford, 200o), $40-45$. 
discussion of specific gravities. ${ }^{6}$ Francis Bacon would have agreed: "to know the Densities and Rarities of bodies, and much more to get hold of and bring about their Condensations and Rarefactions is something of the greatest importance for contemplation and practice."7 To that end, as Dana Jalobeanu shows in her article, he used all of the tools at his disposal in his philosophy of experimentation. But why, in the middle of the sixteenth century, did weight emerge as such an important quantity for natural philosophers in their efforts to study the hidden properties of things?

In part, this new interest in gravimetric measurements was due to a crisis of the Aristotelian notions of absolute heaviness and levity, together with new interpretations of the rarity and density of substances. If, for atomists, measurements of the absolute weights and volumes of substances could easily represent the quantity of homogeneous matter in a body, the situation was much more complex from a traditional Aristotelian point of view. This was because, to use Andrew Pyle's concise assessment, "Aristotelian matter can undergo (intrinsic) condensation and rarefaction": the same quantity of matter can "fill more or less space," without "leaving pores or interstitial vacua." sue can be also rephrased asserting that, in a purely Aristotelian framework, matter "was not taken to possess a fixed absolute volume." Also, measurements of the weight of substances could produce puzzles, because, for instance, if "fire, for a peripatetic, is absolutely light, but nonetheless material," then "adding fire to a compound would increase its quantity of matter but decreases its weight." If so, the "notion that weight could serve as a measure of quantity of matter" did not make sense. ${ }^{10}$

Nevertheless, even in an Aristotelian framework, measurements of weight could still give signs and indications, if not about the quantity of matter, at least of the internal nature of substances. So, for instance, Vannoccio Biringuccio, Gabriele Falloppio and Girolamo Mercuriale could still offer a quantitative explanation of the increase of the weight of lead during calcination, using the Aristotelian notion of an inherently light pneumatic matter. ${ }^{11}$ Moreover, as William Newman has shown, even for Aristotelian alchemists in the Geberian

6 “... ein Philosophus auß fleissiger betrachtung deß Gewichts an einem jeden Zeug trefflich viel / und offtermals mehr erlernen könde / dann ein Alchimist auß dem Fewr," Johannes Kepler, Außzug auß der Uralten Messekunst Archimedis (Linz, 1616), 110.

"Nam \& Densitates \& Raritates Corporum nosse, \& multo magis Condensationes \& Rarefactiones procurare \& efficere, maxime interest \& Contemplativae \& Practicae." Bacon, The Instauratio Magna, 39.

8 Andrew Pyle, Atomism and its Critics. From Democritus to Newton (Bristol, 1997), 298.

9 Robert Pasnau, Metaphysical Themes 1274-1671 (Oxford, 2011), 70.

10 Pyle, Atomism, 298.

11 See Silvia Manzo's article in this special issue. 
tradition of the Summa perfectionis, specific weight could be used to substantiate corpuscular theories about the nature and composition of metals. ${ }^{12}$

One possible way of interpreting the increasingly relevant role of weight in the investigation of substances in the second half of the sixteenth century and one that has already been well-explored - is to consider it a feature of the process by which "the authority of Archimedes" would displace Aristotle. ${ }^{13}$ In fact, Archimedean ideas fitted well with this change of perspective - in particular, the hydrostatic principle of Archimedes could easily explain the apparent weight of bodies in media of different specific gravity without recourse to the Aristotelian concept of inherent levity. This would imply a notion of the "true weight" of a body, in some way linked to its matter. ${ }^{14}$

Certainly, several investigators of the weight of substances based their experiments on the hydrostatic principle of Archimedes, comparing weights in air and water, as for instance in the case of Niccolò Tartaglia, Galileo Galilei, Marino Ghetaldi, and Thomas Harriot. At the same time, however, others - like François de Foix de Candale, Jean Bodin, Juan Bautista Villalpando, Francis Bacon and Johannes Kepler - did not employ hydrostatic methods, but instead measured the weight of equal volumes of different substances in air. Moreover, the study of the specific gravities of substances could happen well beyond the domain of natural philosophy proper. This was the case, for instance, with Juan Bautista Villalpando, a Spanish Jesuit who published his results in his In Ezechielem explanationes, a monumental work offering a reconstruction of the Temple of Solomon based on the interpretation of the vision of the biblical prophet Ezechiel. ${ }^{15}$ Villalpando's measurements, often remarked upon in modern literature for their accuracy, were part of an antiquarian and not natural philosophical - research program, a crucial fact usually overlooked by commentators. Also, the experimentation on metals by Jean Bodin and François de Foix de Candale was related to monetary matters and issues about counterfeiting. ${ }^{16}$

12 William R. Newman, Atoms and Alchemy: Chymistry and the Experimental Origins of the Scientific Revolution (Chicago, IL, 2006), ch. 1; William Newman and Lawrence M. Principe, Alchemy Tried in the Fire. Starkey, Boyle, and the Fate of Helmontian Chymistry (Chicago, IL, 2002), ch. 2.

13 Pyle, Atomism, 357.

14 Ibid., 354.

15 Jerónimo de Prado and Juan Bautista Villalpando, In Ezechielem explanationes et apparatus urbis, ac templi Hierosolymitani: Commentariis et imaginibus illustratus. Opus tribus tomis distinctum. Vol. 3 (Rome, 16o4).

16 See Cesare Pastorino, "Weighing Experience: Experimental Histories and Francis Bacon's Quantitative Program," Early Science and Medicine, 16 (2011), 542-570, at 557-562. 
Several of these non-natural philosophical connections can be discerned in the background of the research documented in the articles contained in this special issue (or are fully addressed in the primary sources, as is the case with Johannes Kepler). In any event, the notions of weight and density, together with their characterization and practical use in natural philosophy and beyond, were a central concern of many authors in the sixteenth and early seventeenth century, and there is still much to be gained from a more concentrated study of their findings.

\section{Acknowledgements}

The preparation of this special issue was supported by the German Research Foundation (DFG) as part of my project The Weight of Things. Quantification of Matter and the Exchange of Technical and Learned Knowledge in Early Modern Europe (project number: 339935097). Early work for this issue was developed in a working group entitled "The Interdisciplinary Reconfiguration of Dense and Rare in Early Modern Europe." Together with the authors featured in this issue, Arianna Borrelli was a key participant in the group, and I would like to thank her for her very valuable contributions to it. 